\title{
The relationship between the heart-type fatty acid binding protein levels, carotid intima media thickness and epicardial fat thickness in patients with obstructive sleep apnea syndrome
}

\author{
Cebrail AZAR ${ }^{1}($ ID) \\ Özlem ABAKAY ${ }^{2}(I D)$ \\ Şengül AZAR ${ }^{3}$ (ID) \\ Tayfun KERMENLi ${ }^{4}$ (ID) \\ Hatice YÜKSEL ${ }^{5}$ (ID)
}

\footnotetext{
${ }^{1}$ Department of Chest Diseases, Medicalpark Elazig Hospital, Elazig, Turkey

${ }^{1}$ Medicalpark Elazığ Hastanesi, Göğüs Hastalıkları Bölümü, Elazığ, Türkiye

2 Department of Chest Diseases, Faculty of Medicine, Dicle University, Diyarbakir, Turkey

${ }^{2}$ Dicle Üniversitesi Tıp Fakültesi, Gögüs Hastalıkları Anabilim Dalı, Diyarbakır, Türkiye

${ }^{3}$ Department of Public Health, Faculty of Medicine, Firat University, Elazig, Turkey

${ }^{3}$ Fırat Üniversitesi Tıp Fakültesi, Halk Sağlığı Anabilim Dalı, Elazı̆̆, Türkiye

${ }^{4}$ Department of Chest Surgery, Medicalpark Elazig Hospital, Elazig, Turkey

${ }^{4}$ Medicalpark Elazığ Hastanesi, Göğüs Cerrahisi Bölümü, Elazı̆g, Türkiye

${ }^{5}$ Department of Biochemistry, Faculty of Medicine, Dicle University, Diyarbakir, Turkey

${ }^{5}$ Dicle Üniversitesi Tıp Fakültesi, Biyokimya Anabilim Dalı, Diyarbakır, Türkiye
}

Cite this article as: Azar $C$, Abakay Ö, Azar S, Kermenli $T$, Yüksel $H$. Real life results of coil treatment for bronchoscopic lung volume reduction in emphysema. Tuberk Toraks 2020;68(1):1-8.

Yazışma Adresi (Address for Correspondence)

\section{Dr. Tayfun KERMENLi}

Medicalpark Elazığ Hastanesi,

Göğüs Cerrahisi Bölümü,

ELAZIĞ - TÜRKIYE

e-mail: tayfunkermenli@gmail.com

CCopyright 2020 by Tuberculosis and Thorax.

Available on-line at www.tuberktoraks.org.com

\section{ABSTRACT}

The relationship between the heart-type fatty acid binding protein levels, carotid intima media thickness and epicardial fat thickness in patients with obstructive sleep apnea syndrome

Introduction: In this study, we aimed to evaluate the relationship between carotid artery intima-media thickness, epicardial fat thickness measurement and the levels of heart-type fatty acid binding protein ( $h F A B P)$ in patients with obstructive sleep apnea syndrome (OSAS).

Materials and Methods: Ninety-nine newly diagnosed OSAS patients and fifty non-OSAS control subjects were enrolled in this study. In both groups, demographic data such as age, sex, body mass index (BMI) were recorded and carotid intima-media thickness (CMIT) and epicardial fat thickness (EFT) were measured. hFABP levels were determined using the enzyme-linked immunosorbent assay (ELISA) method according to the manufacturer's protocols.

Results: Patients with OSAS 67\% male, 33\% female gender is determined. The mean age of control group was $43.28 \pm 12.12$ years and group of OSAS was $47.85 \pm 11.55$ years $(p=0.026)$. In OSAS group; 38 mild OSAS $(38.38 \%), 23$ moderate OSAS (23.23\%) and 38 severe OSAS $(38.38 \%)$ patients were identified. In OSAS patients, average of apnea hypopnea index 
(AHI) was 29.83/hours. A positive correlation was observed between BMI with EFT and CMIT ( $p<0.05)$. $h F A B P$ levels in OSAS group average was $2.65 \pm 2.1 \mathrm{ng} / \mathrm{mL}$ and in control group average was $1.62 \pm 0.90 \mathrm{ng} / \mathrm{mL}$ and this was statistically significant ( $p=0.002)$. $E F T$, in the control group average was $5.3 \pm 2.04 \mathrm{~mm}$, while the average was $4.3 \pm 1.79 \mathrm{~mm}$ in the OSAS group $(p=0.019)$. The correlation was observed between the CMIT and EFT $(p<0.001)$. There was no significant difference in BMI and gender between OSAS and control groups. No accompanying cardiovascular disease was detected in patients with OSAS.

Conclusion: This study suggests EFT and hFABP can be used as a predictive value in determining cardiovascular risk in OSAS patients.

Key words: Obstructive sleep apnea syndrome; heart type fatty acid binding protein; intima-media thickness; epicardial fat thickness

ÖZ

Obstrüktif uyku apne sendromlu hastalarda kalp tipi yağ asidi bağlayıcı protein düzeyleri, karotis intima media kalınlığı ve epikardiyal yă kalınlığı arasındaki ilişki

Giriş: Bu çalışmada obstrüktif uyku apne sendromu (OSAS) olan hastalarda karotid arterlerin intima media kalınlıkları ile epikardiyal yağ kalınlı̆̆ı ölçümlerinin kalp tipi yağ asidi bağlayıcı protein (heart type fatty acid binding protein; hFABP) düzeyleri ile ilişkisini araştırmayı amaçladık.

Materyal ve Metod: Çalışmaya 99 OSAS ve 50 kontrol olgusu dahil edildi. Hasta ve kontrol grubunda serum hFABP düzeyleri ölçüldü. Olguların demografik verileri kaydedildi ve karotis arter intima media kalınlığı (CMIT) ve epikardiyal yağ kalınlıklarının (EFT) ölçümü yapıldı.

Bulgular: OSAS grubunun \%67'si erkek, \%33'ü kadın cinsiyet olarak saptanmıștır. Kontrol grubunun yaş ortalaması $43.28 \pm 12.12$ yıl, OSAS grubunun $47.85 \pm 11.55$ yıl idi $(p=0.026)$. OSAS olan grupta 38 (\%38.38) hastada hafif, 23 (\%23.23) hastada orta, 38 (\%38.38) hastada ağır OSAS tespit edildi. OSAS grubunun AHI ortalaması 29.83/sa idi. Beden kitle indeksi (BKi) ile EFT ve CMIT arasında pozitif korelasyon izlendi $(p<0.05)$. hFABP düzeyi OSAS grubunda ortalama $2.65 \pm 2.1 \mathrm{ng} / \mathrm{mL}$ iken kontrol grubunda ortalama $1.62 \pm 0.90 \mathrm{ng} / \mathrm{mL}$ olarak tespit edildi $(p=0.002)$. CMIT OSAS grubunda ortalama $0.67 \pm 23 \mathrm{~mm}$ iken kontrol grubunda ortalama $0.6 \pm 0.21 \mathrm{~mm}$ idi ( $p>0.05$ ). EFT OSAS grubunda ortalama $5.3 \pm 2.04 \mathrm{~mm}$ iken kontrol grubunda ortalama $4.3 \pm 1.79 \mathrm{~mm} i d i$ $(p=0.019)$. CMIT ve EFT arasında korelasyon izlendi $(p<0.001)$. OSAS'lı hastalar ile kontrol grubu arasında BKi ve cinsiyet açısından anlamlı fark yoktu. OSAS'ı hastalarda eşlik eden kardiyovasküler hastalık saptanmadı.

Sonuç: Bu çalışma OSAS tanısı konulan hastalarda kardiyovasküler riski belirlemede hFABP ve EFT değerlerinin prediktif olarak kullanılabileceğini düşündürmektedir.

Anahtar kelimeler: Obstrüktif uyku apne sendromu; kalp tipi yă̆ asidi bağlayan protein; intima media kalınlığı; epikardiyal yağ kalın$\lg \mathrm{g} I$

\section{INTRODUCTION}

Obstructive sleep apnea syndrome (OSAS) is a clinical condition characterized by breathing stop episodes, sleep fragmentation, oxygen desaturation and increased daytime sleepiness due to recurrent blockages in the upper airway during sleep. OSAS is a disease with a prevalence of $2.8-9 \%$ and a significant morbidity and mortality $(1,2)$. The gold standard for diagnosis is polysomnography.

Systemic arterial hypertension, ischemic heart disease, heart failure, pulmonary hypertension, cardiac arrhythmias, sudden death can be seen with OSAS. It has been reported that carotid intima media thickness (CMIT) can be used for early detection of cardiovascular risk in patients with OSAS (3). The resulting hypoxia and systemic inflammation increases atherosclerosis, thus constituting a risk for cerebrovascular diseases (4).

The heart-type fatty acid binding protein (hFABP), a cardiac marker, is a cytoplasmic protein with a weight of $15 \mathrm{kDa}$, mainly in the heart, circulating and non-cardiac tissues (5). In cell membrane damage, hFABP is released out of the cell and is easily circulated as it is a small molecule (6). In a study investigating whether nocturnal hypoxemia might cause myocardial injury in OSAS patients with no cardiovascular disease, mean hFABP levels were associated with a desaturation period in sleep $(<80 \%)(7)$.

Epicardial fat thickness (EFT) is a visceral fat deposition of the heart, reflecting visceral obesity better than general obesity (8). EFT is an independent factor for visceral adiposity and cardiometabolic risk and in a study investigating the relationship between EFT and OSAS weight, a significant correlation was found between EFT and OSAS disease severity (9). In Akilli's study, the relationship between the effects of sex on leptin and epicardial fat thickness and the severity of OSAS was investigated and it was revealed that leptin and EFT levels in women present more meaningful data in evaluating the severity of OSAS (10). 
In this study, we aimed to investigate whether CMIT, EFT and hFABP levels differed among control patients in OSAS patients and to investigate the correlation between these parameters.

\section{MATERIALS and METHODS}

Permission was obtained from Dicle University Faculty of Medicine Ethics Committee and informed consent was obtained from each participant. The study was planned prospectively and 149 patients who underwent polysomnography in the Dicle University Faculty of Medicine, Department of Chest Diseases Sleep Disorders Center between August 2014 and April 2015 were included to study.

Patients with an apnea hypopnea index $(\mathrm{AHI})<5$ were accepted as control group and those with $\mathrm{AHI}$ $>5$ were accepted in the OSAS group. Patients with OSAS were classified as mild with $\mathrm{AHI} \geq 5-15$, moderate with $\mathrm{AHI}>15-30$ and severe with $\mathrm{AHI}>30$.

Serum heart-type fatty acid-binding protein levels were measured in the patient and control groups. Age, height, weight, body mass index, waist circumference, neck circumference, smoking, polysomnography data, periodic leg movements, oxygen desaturation index (ODI), AHI, CMIT and EFT measurements were performed. The PSG procedure was performed with the devices where the sleep and respiratory parameters were recorded automatically in the sleep center.

Patients were admitted to the sleep center for OSAS because of at least one of the complaints of snoring, witnessed apnea or sleepiness during the day. Cases with at least 240 minutes of sleep time in the polysomnographic records were included in the study. Patients with central apnea, upper airway resistance, hematological disorders, neurological disorders, cardiovascular disease, lung disease, diabetes, active infections, hepatitis, cancer, kidney failure and other metabolic diseases were excluded from the study. Patients using drugs such as dopaminergic drugs, opiates, benzodiazepines and tricyclic antidepressants, etc. were also excluded.

A total of 149 patients who underwent polysomnography and who did not meet the exclusion criteria were included in the study. According to the PSG results, 99 patients were accepted as OSAS and 50 as control patients. Demographic data such as age, gender, body mass index (BMI) were recorded (11).

\section{Polysomnographic Evaluation}

Polysomnography recordings were performed in our Sleep Disorders Center with the Compumedics brand, 44-channel E-series polysomnography device (E-Series Compumedics ${ }^{\mathrm{TM}}$, Melbourne, Victoria, Australia). The patients were monitored for a minimum of 4 hours of sleep. Electroencephalography (EEG) records show the location of the electrodes according to the international 10-20 system; two channels were made as C3/A2 and C4/A1, two electrooculography (EOG), jaw and both tibialis anteroior muscle bipolar surface electromyogram and body position and motion sensors were used. Mouth and nose airflow (with oronasal cannula and thermistor) were measured to monitor respiratory events. Respiratory movements were recorded with the help of thoracic and abdominal bands. Snoring was evaluated with a microphone placed on the larynx to the anterior-upper part of the neck. Oxygen saturation was measured by pulse oximetry during sleep and an electrocardiogram was used. Oxygen desaturation index (ODI) was defined as the number of oxygen desaturation per hour during sleep. Nocturnal oxygen desaturation (NOD) is defined as a decrease in $\mathrm{SaO}_{2}$ of less than $90 \%$ over $30 \%$ of the recording time. All night infrared video was synchronized with polysomnographic data and stored in digital format. PSG recordings were scored according to the standard criteria of Rechtschaffen and Kales in $30 \mathrm{sec}$ epokes (12).

The sleep phase at the PSG was determined according to the American Academy of Sleep Medicine (AASM) 2007 criteria. Apnea and hypopnea were defined according to AASM criteria. Data were expressed as apnea-hypopnea index (AHI) and apnea-hypopnea/hour numbers were calculated. AHI $\geq 5$ is the diagnosis of OSAS (13). Leg movements (LMS) were also scored according to AASM 2007 criteria (13). A series of periodic leg movements is called as four or consecutive LMS between 5-90 sec during sleep (13). PLMS index (PLMSI) was defined by dividing total PLM events by total sleep time in PSG.

\section{Echocardiographic Evaluation}

Carotid artery doppler ultrasound was performed by Phillips $4000 \mathrm{HDI}$ device and 7-12 MHz linear probe. In patients with thick and short neck, bilateral carotid artery Doppler US examination was performed with 4-7 MHz linear probe. Patients were 
placed in the supine position, $1 \mathrm{~cm}$ after the bifurcation of both internal carotid arteries (ICA), where the hemodynamics were least affected, at the transverse plane and at the diastolic stage; The effects of ICA on intima-media thickness and epicardial fat thickness were investigated. In addition, factors that cause carotid artery CMIT have been analyzed in patients with OSAS. Measurements were made with B-mode US and colored doppler US was used to exclude only hypoechoic and calcific plaques. Patients with hypoechoic and calcific plaques were excluded from the study.

\section{Laboratory Analysis}

After PSG, minimal tourniquet was applied from each participant and $8 \mathrm{~mL}$ blood was taken from the antecubital vein. It was analyzed by ELIZA (enzymelinked immunosorbent assay) method in Dicle University Medical Faculty Biochemistry Laboratory. CRP levels were performed by nephelometric method. Cholesterol, fasting triglyceride, HDL-cholesterol and fasting blood sugar plasma concentrations were measured using Cobas 6000 (Roche Diagnostics $\mathrm{GmbH}$, Mannheim, Germany). LDL cholesterol values were calculated according to the Friedewald formula.

\section{Statistical Analysis}

SPSS 15.0 for windows statistical package program was used for statistical evaluation of our data. Measured variables were presented with mean \pm standard deviation and categorical variables with number and percentage (\%). The data were compared with the normal distribution of KolmogorovSmirnov Test. Student's t-test was used for comparison of normal-distributed study and control group parameters while Mann-Whitney $U$ test was used for parameters not showing normal distribution. Chisquare test was used to compare qualitative data. Pearson correlation test was used for the parameters which were normally distributed, and Spearmanesindes rho correlation test was used for the parameters that did not show normal distribution. The results were evaluated with a confidence interval of $95 \%$ and a significance level of $p<0.05$.

\section{RESULTS}

Of the 149 patients with complaints of daytime sleepiness and snoring, 99 of them had $\mathrm{AHI} \geq 5$ OSAS in their PSG. We found AHI $<5$ in 50 of the PSG. 99 patients with $\mathrm{AHI} \geq 5$ were enrolled as a study group. The control group consisted of 50 patients with $\mathrm{AHI}<5$. OSAS patient group; $38 \%$ were mild OSAS, $23 \%$ were middle OSAS and $38 \%$ were severe OSAS.

The demographic characteristics of the patients were female $32(32.3 \%)$ and male $67(67.7 \%)$ in the OSAS group. The number of women in the control group was $21(42 \%)$, male $29(58 \%)$. There was no significant difference in gender distribution between the control and OSAS patient groups $(p=0.244)$. There was no significant difference in terms of gender in OSAS subgroups $(p=0.691)$ (Table 1$)$.

When the patients were evaluated in terms of age; the mean age of the OSAS group was $47.85 \pm 11.55$ years and the mean age of the control group was $43.28 \pm$ 12.12 years. The mean age of patients in the mild OSAS group was $46.55 \pm 12.48$ years, the mean age was $49.39 \pm 10.21$ years in the middle OSAS group and the mean age in the severe OSAS group was $48.23 \pm 11.51$ years. The mean age of the control group was significantly lower than the OSAS group $(p=0.026)$. There was no significant difference in mean age between OSAS groups $(p=0.530)$ (Table 1).

Of the 149 cases, 1 was normal weight (BMI $\geq 18-27$ ) $(0.7 \%), 30$ cases were underweight $(\mathrm{BMI}<18)$ (20.1\%), 67 cases were obese (BMI > 27-35) $(45 \%)$. 51 patients were morbid obesity $(\mathrm{BMI}>35)(34.2 \%)$

Table 1. Demographic distribution of the patients and BMI, ODI values

\begin{tabular}{|c|c|c|c|}
\hline & OSAS group & Control group & $\mathbf{p}$ \\
\hline Female & $32(32.3 \%)$ & $21(42 \%)$ & 0.244 \\
\hline Male & $67(67.7 \%)$ & $29(58 \%)$ & \\
\hline Age & $47.85 \pm 11.55$ & $43.28 \pm 12.12$ & 0.026 \\
\hline BMI & $33.59 \pm 5.6$ & $32.08 \pm 4.1$ & $<0.25$ \\
\hline ODI & $35.2 \pm 27.7$ & $9 \pm 11.89$ & $<0.05$ \\
\hline
\end{tabular}


(Table 2). The mean BMI of the control group was not significantly different from the OSAS patient group $(p<0.25)$. There was a positive correlation between BMI and EFT and CMIT ( $p<0.05, r=0.394, r=0.297)$.

In our study, there were no patients with normal weight in the OSAS patient group. $15.2 \%$ of the patients with OSAS were overweight, $46.5 \%$ were obese and $38.4 \%$ were morbid obese. There was no difference in the frequency of BMI subgroups between the OSAS group and the control group $(p=0.064)$.

When we classified the groups according to $\mathrm{AHI}$, the mean AHI was 29.83 units / hours in the OSAS group and 2.2 units/hours in the control group $(p<0.001)$. Apnea index was found to be elevated as the disease severity increased in the OSAS subgroups $(p<0.001)$.

Oxygen Desaturation Index (ODI) was $35.2 \pm 27.7$ in the OSAS group and $9 \pm 11.89$ in the control group $(p<0.05)$. As the severity of the disease increased in the OSAS subgroups, ODI was significantly increased $(p<0.05)$ (Table 1). There was a positive correlation between ODI, \%NOD values and CMIT, EFT values, these were significant $(p<0.05)$. However, no significant correlation was found between ODI, \%NOD and hFABP $(p=0.78, p=0.103)$. There is a statistically significant negative correlation between $\mathrm{minSpO}_{2}$ and CMIT, EFT $(p<0.05)$, there is no correlation with hFABP $(p=0.72)$.

The mean period of leg movements in sleep was 6.4 \pm 1.24 units/hours in the OSAS group and $9 \pm 2.39$ units/hours in the control group, and the difference was not significant $(p=0.408)$.

The mean waist circumference was $111.8 \pm 7.1 \mathrm{~cm}$ in the OSAS group and $106.4 \pm 5.8 \mathrm{~cm}$ in the control group $(p<0.05)$. As the severity of OSAS increased, there was a significant increase in waist circumference $(p<0.003)$. The mean circumference of the neck was $41.01 \pm 2.9 \mathrm{~cm}$ in the OSAS group and $39.9 \pm$ $1.63 \mathrm{~cm}$ in the control group $(\mathrm{p}=0.088)$. There was no significant difference in OSAS subgroups. There was a positive correlation between waist circumference and EFT and CMIT values $(p<0.05, r=0.381$, $r=$ $0.320)$. There was a positive correlation between neck circumference and EFT and CMIT $(p<0.05, r=$ $0.366, r=0.269$ ) (Table 3).

Carotid intima-media thickness and epicardial fat thickness; the mean CMIT was $0.67 \pm 23 \mathrm{~mm}$ in the OSAS group and the mean CMIT in the control group was $0.6 \pm 0.21 \mathrm{~mm}(p=0.409)$. There was no statistically significant difference in CMIT between the OSAS patient subgroups. The mean EFT in the OSAS

Table 2. Distribution of BMI and AHI values in OSAS patients

\begin{tabular}{|c|c|c|c|c|c|}
\hline \multicolumn{2}{|c|}{ OSAS patients $(n=99)$} & $\mathrm{AHI}=5-15$ & $\mathrm{AHI}=16-30$ & $\mathrm{AHI}>30$ & $n=99$ \\
\hline \multirow[t]{5}{*}{ BMI groups } & $\mathrm{BMI}<18$ (underweight) & 10 & 2 & 3 & 15 \\
\hline & $\mathrm{BMI} \geq 18-27$ (normal) & - & - & - & - \\
\hline & BMI > 27 (obese) & 18 & 14 & 14 & 46 \\
\hline & BMI $>35$ (morbid obese) & 10 & 7 & 21 & 38 \\
\hline & n (\%) & $38(38.4 \%)$ & $23(23.2 \%)$ & $38(38.4 \%)$ & $99(100 \%)$ \\
\hline
\end{tabular}

Table 3. Clinical tests and examinations results of the patients

\begin{tabular}{|c|c|c|c|}
\hline & OSAS group & Control group & $\mathbf{p}$ \\
\hline Periodic leg movement $(\mathrm{n} / \mathrm{h})$ & $6.4 \pm 1.24$ & $9 \pm 2.39$ & 0.408 \\
\hline Mean waist circumference $(\mathrm{cm})$ & $111.8 \pm 7.1$ & $106.4 \pm 5.8$ & $<0.05$ \\
\hline Mean neck circumference $(\mathrm{cm})$ & $41.01 \pm 2.9$ & $39.9 \pm 1.63$ & 0.088 \\
\hline CMIT (mm) & $0.67 \pm 0.23$ & $0.6 \pm 0.21$ & 0.409 \\
\hline $\mathrm{EFT}(\mathrm{mm})$ & $5.3 \pm 2.04$ & $4.3 \pm 1.79$ & 0.019 \\
\hline hFABP (ng/mL) & $2.65 \pm 2.1$ & $1.62 \pm 0.90$ & 0.002 \\
\hline C-reactive protein (mg/dL) & $0.93 \pm 0.65$ & $0.93 \pm 0.93$ & 0.383 \\
\hline
\end{tabular}


group was $5.3 \pm 2.04 \mathrm{~mm}$ and the mean EFT in the control group was $4.3 \pm 1.79 \mathrm{~mm}(p=0.019)$. There was no statistically significant difference between the OSAS patient subgroups in terms of EFT $(p=0.019)$. There was a correlation between CMIT and EFT values $(p<0.001, r=0.468)$ (Table 2$)$.

The mean of hFABP in the OSAS group was $2.65 \pm 2.1$ $\mathrm{ng} / \mathrm{mL}$ and the mean of $\mathrm{hFABP}$ was $1.62 \pm 0.90 \mathrm{ng} / \mathrm{mL}$ in the control group $(p=0.002)$. There was no statistically significant difference in hFABP levels between the OSAS patient subgroups and there was no correlation between hFABP level and CMIT and EFT values (Table 3). Therefore, the risk of cardiovascular disease was similar between the OSAS patient groups.

C-reactive protein (CRP) was accepted as a marker because patients suspected of infection have excluded from the study. CRP level was found to be $0.93 \pm$ $0.95 \mathrm{mg} / \mathrm{dL}$ in the control group $(\mathrm{n}=19)$ and $0.93 \pm$ $0.93 \mathrm{mg} / \mathrm{dL}$ in the OSAS group $(\mathrm{n}=32)$. CRP levels were not statistically significant in the control and patient groups ( $p=0.383$ ) (Table 2$)$. The rate of smokers was $45 \%$ in the OSAS group and $52 \%$ in the control group. There was no significant difference between OSAS and control groups in terms of total cholesterol, triglyceride, HDL and LDL levels in terms of lipid profile $(p=0.7909)$. However, LDL and total cholesterol levels were found to be significantly increased as the severity of the disease increased among the OSAS patient subgroups $(p<0.05)$.

\section{DISCUSSION}

Obesity plays an important role in the pathophysiology of OSAS. In studies, weight gain was shown to cause a large increase in snoring and daytime sleepiness $(14,15)$. OSAS was reported in $50-81 \%$ of obese patients $(15,16)$. In the series of Garg et al., 81 $(44.4 \%)$ were non-obese and 45 (55.6\%) were obese (16). In our study, the ratio of obese patients was $45 \%$ and morbidly obese patients was $34 \%$ in the OSAS group. In addition, there was a positive correlation between BMI and EFT and CMIT values $(p<0.05)$.

Similar to the literature, we found high body mass index in the OSAS patient group. Neck circumference and $\mathrm{BMI}$ are largely related. The relationship between the severity of respiratory distress and waist circumference in adults is stronger than that of the neck circumference (17).

It is evaluated with $\mathrm{AHI}$, which determines the clinical severity of OSAS. Şahbaz et al. classified 80 patients with OSAS according to AHI, and found 26 $(32 \%)$ as mild, $15(19 \%)$ as moderate and $39(49 \%)$ as severe OSAS (18). In our study, we found mild $(38.38 \%)$ in 38 patients, moderate $(23.23 \%)$ in 23 patients, and severe OSAS in 38 patients $(38.38 \%)$ in the OSAS group.

When OSAS patients were compared with the control group, it was found that the minimum and average oxygen saturation in sleep were low and desaturation indices were higher (19). In our study, ODI was found to be $9 \pm 11.89$ in the control group and $35.2 \pm 27.7$ in the OSAS group. The mean ODI in the control group was significantly lower than the OSAS patient group ( $p<0.05$ ). OSAS severity was significantly higher in patients with OSAS patients $(p<0.05)$.

Periodic leg movements in sleep (PLMS) are characterized by periodic, stereotypic extension movements in the legs, often in the ankle. It is accepted as pathological if the number of movements per hour in adults is over 15 (20). In one study, PLMS was found to be higher in OSAS patients (21). In our study, no difference was found between the OSAS group and the control group in terms of PLMS.

There are serious data about the hypoxia occurring in OSAS leading to endothelial dysfunction due to oxidative stress $(22,23)$. Köktürk et al. and Lavie et al. in two different studies, there was no statistically significant difference between the groups in terms of total cholesterol, triglyceride, HDL and LDL levels like results of our study $(24,25)$.

There are different opinions about whether nocturnal hypoxemia may cause myocardial injury in OSAS patients with no cardiovascular disease (26). In a review study, mean hFABP levels were reported to be related to sleep desaturation period (27). High levels of hFABP have been associated with OSAS and metabolic syndrome (28).

CMIT increase in OSAS patients is an indicator of atherosclerosis and is an independent risk factor for cerebrovascular diseases (29). Lubrano et al. the relationship between body fat distribution and disease was investigated in patients with OSAS, and the results were related to both cardiac adipocyte and abnormal body fat distribution in obese patients (30). Significant increases in left ventricular mass and CMIT were detected in these patients (30).

Epicardial fat is the visceral fat deposition of the heart and reflects visceral obesity better than general obe- 
sity (31). In our study, there was a correlation between CMIT and EFT ( $p<0.001, r=0.468)$.

\section{CONCLUSION}

Inflammatory cytokines and neurohormones play a role in various mechanisms in cardiovascular pathophysiology; It is associated with the severity of the disease and adversely affects the prognosis. Chronic recurrent hypoxemia and ischemia have an important role in inflammation. Prevention of future cardiovascular complications in patients with sleep apnea, after a good history and a complete physical examination; analysis of cardiovascular markers such as hFABP, CMIT and EFT, if necessary; It will be possible to prevent, reduce or control the global risks that cause cardiovascular disease such as hypertension, obesity, diabetes or metabolic syndrome, dyslipidemia and smoking.

\section{CONFLICT of INTEREST}

There is no conflict of interest related to this study.

\section{AUTHORSHIP CONTRIBUTIONS}

Concept/Design: CA, ÖA

Analysis/Interpretation: CA, ŞA, HY

Data Acquisition: CA, ŞA

Writting: CA, TK

Critical Revision: CA, ŞA, TK

Final Approval: All of authors

\section{REFERENCES}

1. Wali SO, Abalkhail B, Krayem A. Prevalence and risk factors of obstructive sleep apnea syndrome in a Saudi Arabian population. Ann Thorac Med 2017;12:88-94.

2. Jennum P, Riha RL. Epidemiology of sleep apnea/hypopnea syndrome and sleep-disordered breathing. Eur Respir J 2009;33:907-1225.

3. Liao LJ, Cho TY, Huang TW. Assessment of carotid artery intima-media thickness in patients with obstructive sleep apnoea. Clin Otolaryngol 2017;42:974-8.

4. Güney E, Arslan M, Şalk I, Doğan OT, Akkurt I. Carotid artery on the effect of obstructive sleep apnea syndrome. Cumhuriyet Med J 2010;32:288-94.

5. Alhadi HA, Fox KA. Do we need additional markers of myocyte necrosis: the potential value of heart fatty acid binding protein. Q / Med 2004;97:187-98.

6. Otaki Y, Watanabe T, Kubota I. Heart-type fatty acidbinding protein in cardiovascular disease: A systemic review. Clin Chim Acta 2017;474:44-53.
7. Sato M, Inoue S, Igarashi A, Tokairin Y, Sato K, Nakano H, et al. Heart-type fatty acid binding protein as a prognostic factor in patients with exacerbated chronic obstructive pulmonary disease. Respir Investig 2018;56:128-35.

8. lacobellis G, Willens HJ. Echocardiographic epicardial fat: a review of research and clinical applications. I Am Soc Echocardiogr 2009;22:1311-9.

9. Mariani S, Fiore D, Barbaro G, Basciani S, Saponara M, D'Arcangelo E, et al. Association of epicardial fat thickness with the severity of obstructive sleep apnea in obese patients, Int J Cardiol 2013;167:2244-9.

10. Akilli H, Kayrak M, Bekci TT, Erdogan Hi, Aribas A, Yildirim $O$, et al. Gender-related changes of the epicardial fat thickness and leptin in obstructive sleep apnea. Echocardiography 2014;31:411-9.

11. Van Itallie TB. Prevalence of obesity. Endocrinol Metab Clin North Am 1996;25:887- 905.

12. Rechtschaffen A, Kales A. A manual of standardized terminology, techniques, and scoring system for sleep stages in human subjects. LosAngeles: Brain Information Service, UCLA, 1968.

13. Iber C, Ancoli-Israel S, Chesson A, Quan SF. In American Academy of Sleep Medicine, editor. The AASM manual for the scoring of sleep and events: rules, terminology and technical specifications. Westchester (IL): American Academy of Sleep Medicine, 2007:23-31, 41-3, 45-7.

14. Cross NE, Harrison CM, Yee BJ, Grunstein RR, Wong KK, Britt HC, Marshall NS. Management of snoring and sleep apnea in Australian primary care: the BEACH Study (2000-2014). J Clin Sleep Med 2016;12:1167-73.

15. Li C, Ford ES, Zhao G, Croft JB, Balluz LS, Mokdad AH. Prevalence of self-reported clinically diagnosed sleep apnea according to obesity status in men and women: National Health and Nutrition Examination Survey. Prev Med 2010;51:18-23.

16. Garg R, Singh A, Prasad R, Saheer S, Jabeed P, Verma R. A comparative study on the clinical and polysomnographic pattern of obstructive sleep apnea among obese and nonobese subjects. Ann Thorac Med 2012;7:26-30.

17. Tom C, Roy B, Vig R, Kang DW, Aysola RS, Woo MA, et al. Correlations between waist and neck circumferences and obstructive sleep apnea characteristics. Sleep Vigil 2018;2:111-8.

18. Şahbaz S, itil O, Inönü H, Öztura i, Yemez B, Baklan B, et al. Quality of life, frequency of anxiety and depression in obstructive sleep apnea syndrome. Turk Toraks Derg 2008:9:141-5.

19. Dahy KG, Takahashi K, Saito K, Kakeno A, Kiso H, Isobe Y, et al. The relationship between cephalogram analysis and oxygen desaturation index during sleep in patients submitted for mandibular setback surgery. I Craniofac Surg 2018;29:375-80 
20. Zucconi M, Ferri R, Allen Baier PC, Bruni O, Chokroverty $S$. The official World Association of Sleep Medicine (WASM) standards for recording and scoring periodic leg movements in sleep (PLMS) and wakefulness (PLMW) developed in collaboration with a task force from the International Restless Legs Syndrome Study Group (IRLSSG). Sleep Med 2006;7:175-83.

21. Baran AS, Richert AC, Douglass AB, May W, Ansarin K. Change in periodic limb movement index during treatment of obstructive sleep apnea with continuous positive airway pressure. Sleep 2003;26:717-20.

22. Trzepizur W, Bironneau V, Recoquillon S, Priou P, Meslier $N$, Hamel JF, et al. Polyphenols have no impact on endothelial function in patients with obstructive sleep apnea: a randomized controlled trial. J Nutr 2018;148:5816.

23. Kanbay A, Kaya E, Büyükoğlan H, Kaya MG, Şimşek ZÖ, Tutar $N$, et al. Correlation between pentraxin-3 and endothelial dysfunction in obstructive sleep apnea syndrome. Ann Thorac Med 2015;10:199-203.

24. Kokturk O, Ciftci TU, Mollarecep E, Ciftci B. Serum homocysteine levels and cardiovascular morbidity in obstructive sleep apnea sydrome. Respir Med 2006;100:536-41.

25. Lavie L, Perelman A, Lavie P. Plasma homocysteine levels in obstructive sleep apnea: association with cardiovascular morbidity. Chest 2001;120:900-8.
26. Kendzerska T, Leung RS, Aaron SD, Ayas N, Sandoz JS, Gershon AS. Cardiovascular outcomes and all-cause mortality in patients with obstructive sleep apnea and chronic obstructive pulmonary disease (overlap syndrome). Ann Am Thorac Soc 2019;16:71-81.

27. Dursunoğlu D, Dursunoğlu N. Cardiovascular biomarkers in clinical practice of sleep apnea. Tuberk Toraks 2011;59:402-8.

28. Akbal E, Özbek M, Güneş F, Akyürek Ö, Üreten K, Delibaşı T. Serum heart type fatty acid binding protein levels in metabolic syndrome. Endocrine 2009;36:433-7.

29. Manios E, Tsivgoulis G, Koroboki E, et al. Impact of prehypertension on common carotid artery intima-media thickness and left ventricular mass. Stroke 2009;40:1515-8.

30. Lubrano C, Saponara M, Barbaro G, Specchia P, Addessi E, Costantini $D$, et al. Relationships between body fat distribution, epicardial fat and obstructive sleep apnea in obese patients with and without metabolic syndrome. PLoS One 2012;7:47059.

31. Beşir FH, Yazgan S, Celbek G, Aydın M, Yazgan O, Erkan $M E$, et al. Normal value correlates of carotid intima-media thickness and affecting parameters in healthy adults. Anadolu Kardiyol Derg 2012;12:427-33. 